\title{
Thanks for the Memories!
}

\author{
Arthur M. Michalek ${ }^{1}$ \\ Published online: 7 July 2018 \\ (C) American Association for Cancer Education 2018
}

The great Detroit Tigers sportscaster, Ernie Harwell, once said "It's time to say goodbye, but I think goodbyes are sad and I'd much rather say hello. Hello to a new adventure. "And so, as I pen my last editorial, may I wish you all a great new adventure. I know that I am looking forward to whatever adventures come my way. And I must say that my tenure as Editor in Chief of the Journal of Cancer Education has been a memorable adventure. It is now time for me to move on and make way for new leadership, fresh ideas, and vitality. Our new Editor will be Maria Bishop, MD. Dr. Bishop is a Professor of Medicine at the University of Arizona, and a member of the University of Arizona Cancer Center in Tucson. She is a medical oncologist and chair of the ethics committee at the Southern Arizona Veterans Administration Health Care System (SAVAHCS). Many of you undoubtedly know her and can attest that she is not only a fierce advocate for cancer education, but a most intelligent, compassionate, and sincere individual. I have had the privilege of knowing and working with Maria for a number of years and can rest easy that the Journal will be under the best possible stewardship. She has great plans for the Journal, plans that will lead it to ever greater heights. She will expound upon these ideas in her editorial in the next issue of the JCE. I trust that you will all join me in not only wishing her the best but working closely with her to make her visions for the JCE a reality!

In my first editorial I noted that it was written "with great pride and a certain amount of trepidation" [1]. I felt rather intimidated and inadequate to follow in the footsteps of Drs. Richard Bakemeier and Joseph O'Donnell. Both of whom I noted were "in their own inimitable way responsible for the growth of the Journal and its recognition as the source for thoughtful presentations and reflections in the field of cancer

Arthur M. Michalek

amm3@buffalo.edu

1 University at Buffalo, Buffalo, NY, USA education." The past six years have truly put me to the test. Whatever successes I may have had have not been due to my own efforts, but to OUR efforts. One thing you learn as Editor is that it is not a one-person job. The Journal succeeds or fails based on the work of its authors, reviewers, and editorial board. I owe a great deal of thanks to all. We owe a debt of gratitude to the authors for not only sharing their unique experiences but having the insight and fortitude to develop and conduct innovative cancer educational programming. In the very first issue of the JCE, Dr. Bakemeier wrote that the Journal "will facilitate the dissemination of proven, successful cancer education methods and will stimulate the development of innovative approaches to the cancer education needs of learners at all levels" [2]. The JCE has remained true to these goals. Each and every issue of the JCE provides proof. I have been involved in cancer education, and proudly associated with the American Association for Cancer Education, since before the Journal was born. I recall the early years when the Journal was just an idea and one that some thought would not go much further. Dick Bakemeier was not dissuaded and persevered. The first issue of the Journal ran 57 pages and contained six articles, four book reviews, three letters, and an editorial. This was expanded under Dr. O'Donnell's tenure to four issues a year. Today we stand at six issues per year each running approximately 200 pages. We've come a long way. Not only have we grown in quantity, but also quality. Again thanks to the authors and reviewers the impact factor of the JCE has continued to grow. I have no doubt that we have not yet witnessed its peak and look forward to the impact of Dr. Bishop's guidance.

Dr. Joe O'Donnell was always proud of the fact that the Journal was home to many an authors first publication. This was not because he set lower standards for first authors, but because he encouraged all reviewers to be constructive. We are, after all, a Journal of education. Therefore, we should educate not only the readers of the Journal, but the authors. I thank today's reviewers for continuing this fine tradition of rigorous yet constructive reviews. These reviews have led to stronger final manuscripts and have therefore enhanced the 
overall quality of the JCE. During my tenure we have succeeded in reducing the time for selection of reviewers and receiving first reviews. As an addendum to this editorial I listed the names of all those reviewers split contributed to the JCE this year. I have tried not to overburden any one of you and thank you all for being so giving of your time and knowledge.

A special thanks goes to our entire Editorial Board. Your contribution as reviewers as well as to the advice you have afforded me has made the Journal what it is today. I am especially indebted to our Deputy Editor-in-Chief, John Vetto, M.D. I came to know John very well in the early 1980s when I followed him as President of the AACE. He is a wise man whose counsel I have always valued. He is a man of scholarship, compassion, and possesses sound judgement. During my tenure as Editor the JCE became more international. We evolved from a largely North American venture coupled with significant contributions from our European colleagues to one that is today truly international and regularly presents work from the four corners of the world. Our international outreach has been greatly facilitated by Dr. Amr Soliman who was appointed Deputy Editor for International Submissions during my tenure. He has been especially impactful in developing significant contributions from Africa as well as the Middle East. I look forward to many more adventures with him. While I cannot thank each individual Associate Editor due to space limitations, please know that you have each played a central role in the success of this Journal. Thank you! One Associate Editor in particular has played an invaluable role in my development as both a scientist, person and editor and that is Dr. Bob Chamberlain. Bob has been a mentor to many of us. His breath and depth of knowledge is truly remarkable. He is always quick to respond to questions ranging from scientific methodological issues to how to rebuild an automobile engine. Thank you.

Thank you to my immediate predecessor, Dr. Joe O'Donnell. I first knew Joe as a presenter at various AACE (now ICEC) meetings. He was always there making insightful comments on a myriad of presentations. Our relationship eventually transformed to one of colleagues and eventually as friends. We have enjoyed many adventures and conversations on cancer education, philosophy, history and sports (we are fellow Red Sox fans). My wife, Terry $\mathrm{O}$, and I are quite thankful for our friendship with Joe and his wife Janice.

And last, but certainly not least, I offer my greatest thanks to Terry O'Dea Michalek. We have known each other since high school and she has come to be my most cherished advisor. If or not for her support and advice I don't know where I would be. The Lord could not have blessed me with a greater partner and friend. May we have many more years of adventure!

And may I conclude by quoting one of America's greatest philosophers... Bob Hope. [3]
We who could laugh over big things

Were parted by only a slight thing.

I wonder if we did the right thing,

Oh, well, that's life, I guess,

I love your dress.

Awfully glad I met you,

Cheerio and toodle-oo

Thank you,

Thank you so much.

Be well!

Arthur M. Michalek, PhD, FACE

\section{Appendix}

List of Reviewers; 2018 (as of Editorial date)

\begin{tabular}{|c|c|}
\hline Last Name & First Name \\
\hline Alderfer & Melissa \\
\hline Al-Zadjali & Manal \\
\hline Anggondowati & Trisari \\
\hline Ayala-Marín & Alelí \\
\hline Baima & Jennifer \\
\hline Balkrishnan & Rajesh \\
\hline Barton & Michael \\
\hline Bishop & Maria \\
\hline Borrell & Luisa \\
\hline Brant & Janine \\
\hline Byrd & Theresa \\
\hline Camacho-Rivera & Marlene \\
\hline Challinor & Julia \\
\hline Chamberlain & Robert \\
\hline Chang & Shine \\
\hline Chen & Baojiang \\
\hline Compaore & Salomon \\
\hline Cueva & Katie \\
\hline Cunningham-Erves & Jennifer \\
\hline de Vries & Jakob \\
\hline de Walden-Gałuszko & Krystyna \\
\hline Demoor & Janet \\
\hline Dube & Catherine \\
\hline Elliott & Thomas \\
\hline Erwin & Deborah \\
\hline Ettinger & Susan \\
\hline Evans & William \\
\hline Faupel-Badger & Jessica \\
\hline Ford & Sabrina \\
\hline Glover-Kudon & Rebecca \\
\hline Golden & Daniel \\
\hline Goodman & Melody \\
\hline Gronemeyer & Suzanne \\
\hline Gwede & Clement \\
\hline Hablas & Mohamed \\
\hline Hahn & Erin \\
\hline Haider & Muhiuddin \\
\hline Hardy & Elaine \\
\hline Hassel & Bret \\
\hline Heneghan & Kathleen \\
\hline Heron & Jean-François \\
\hline Hoffman-Goetz & Laurie \\
\hline
\end{tabular}




\begin{tabular}{|c|c|c|}
\hline James & Aimee & References \\
\hline Jégoux & Franck & \\
\hline Johnstone & Candice & \\
\hline Joshi & Ashish & 1. Michalek AM (2013) In Praise of Janus! J Cancer Educ 28(3):213- \\
\hline Kapoor & Neelkamal & 214 \\
\hline Kasting & Monica & 2. Bakemeier R (1986) Editorial. J Cancer Educ 1(1):1 \\
\hline Kepka & Deanna & 3. Thanks For The Memories. Bob Hope and Shirley Ross. The Big \\
\hline Krebs & Linda & Broadcast of 1938, soundtrack. DECCA, MCA. \\
\hline Kuten-Shorrer & Michal & \\
\hline Latini & David & \\
\hline Lewis & Marquita & \\
\hline $\mathrm{Li}$ & Shijian & \\
\hline Linnenbringer & Erin & \\
\hline Madanat & Hala & \\
\hline Mahoney & Martin & \\
\hline McDonald & Fiona & \\
\hline McWhirter & Jennifer & \\
\hline Meade & Cathy & \\
\hline Messner & Carolyn & \\
\hline Michalek & Arthur & \\
\hline Morgan & Robert & \\
\hline Msami & Khadija & \\
\hline Mullan & Patricia & \\
\hline Nicks & Shannon & \\
\hline Nyhof Young & Joyce & \\
\hline O’Donnell & Joseph & \\
\hline O’Connor & Richard & \\
\hline Quintana & Yuri & \\
\hline Radecki Breitkopf & Carmen & \\
\hline Rodriguez & Elisa & \\
\hline Rosenthal & Meagen & \\
\hline Sadler & Georgia & \\
\hline Santos-Silva & Filipe & \\
\hline Schuitevoerder & Darryl & \\
\hline Seifeldin & Ibrahim & \\
\hline Shash & Emad & \\
\hline Shukla & Anubhuti & \\
\hline Smith & Brittney & \\
\hline Solares & Arturo & \\
\hline Soliman & Amr & \\
\hline Soliman & Ann & \\
\hline Soliman & Ghada & \\
\hline Stamler & Lynnette & \\
\hline Starmer & Darren & \\
\hline Szumacher & Ewa & \\
\hline Taber & Jennifer & \\
\hline Tarasenko & Yelena & \\
\hline Tarkowski & Radoslaw & \\
\hline Torres & Essie & \\
\hline Vetto & John & \\
\hline Vinson & Eric & \\
\hline Walters & Chasity & \\
\hline Waterbor & John & \\
\hline Wigfall & Lisa & \\
\hline Wool & Margaret & \\
\hline Yassine & May & \\
\hline
\end{tabular}

